\title{
Hubungan Kualitas Pelayanan, Kepuasan Pelanggan, Dan Loyalitas Pelanggan Pada Pengguna Transportasi Daring
}

\author{
Errica Liongelina Jacksen dan Frangky Slamet \\ Program Studi Manajemen Fakultas Ekonomi Universitas Tarumanagara, Jakarta \\ Email: errica_lj@yahoo.com
}

\begin{abstract}
All society around the world has changed their life significantly because of technological advances, one of them is online transportation. The purpose of this research is to determine that there is a relationship between service quality, customer satisfaction, and customer loyalty towards online transportation users in Jakarta: customer satisfaction as a mediator. The research is done with purposive sampling. Researcher distributes questionnaires to 100 respondents who are the user of online transportation in Jakarta. The result of this study indicates that there is a relationship between service quality, customer satisfaction and customer loyalty towards users of online transportation in Jakarta: customer satisfaction as a mediator.
\end{abstract}

Keywords: Service Quality, Customer Satisfaction, Customer Loyalty, Online Transportation

\begin{abstract}
Abstrak: Masyarakat dunia telah mengubah hidupnya secara signifikan karena kemajuan teknologi, salah satunya adalah transportasi daring. Tujuan penelitian ini adalah untuk mengetahui apakah adanya hubungan kualitas pelayanan, kepuasan pelanggan, dan loyalitas pelanggan pada pengguna transportasi daring di Jakarta: kepuasan pelanggan sebagai mediator. Teknik pengambilan sampel dilakukan dengan purposive sampling. Kuesioner disebarkan pada 100 responden di Jakarta yang merupakan pengguna transportasi daring. Hasil dari penelitian ini menunjukkan bahwa adanya hubungan kualitas pelayanan, kepuasan pelanggan, dan loyalitas pelanggan serta kepuasan pelanggan sebagai mediator.
\end{abstract}

Keywords: Kualitas Pelayanan, Kepuasan Pelanggan, Loyalitas Pelanggan, Transportasi Daring

\section{LATAR BELAKANG}

Masyarakat dunia telah mengubah hidupnya secara signifikan karena kemajuan teknologi, salah satunya adalah transportasi daring (CNBC Indonesia, 2018). Kini, jenis transportasi yang diinginkan dapat dipanggil hanya dengan beberapa sentuhan pada seluler atau telepon genggam pribadi. Ini merupakan salah satu inovasi terbaru dalam m-dagang. Transportasi daring adalah sebuah layanan transportasi di mana pelanggan dapat memesan tumpangan (mobil, sepeda motor, dan lain-lain) melalui aplikasi seluler dan seorang 
pengemudi dapat menanggapi pesanan pelanggan melalui aplikasi (Wallsten, 2015). Di Indonesia, layanan transportasi daring yang beroperasi adalah GO-JEK dan Grab.

Menurut Aydin dan Ozer (2005), kualitas pelayanan merupakan sebuah faktor utama yang strategis dalam diferensiasi suatu produk untuk meningkatkan pangsa pasar dan meningkatkan laba. Hapsari, Clemes, dan Dean (2016) mengidentifikasi bahwa adanya hubungan yang kuat antara kualitas pelayanan dan kepuasan pelanggan. Menurut Lee (2013), kepuasan dapat dianggap sebagai penilaian bahwa suatu layanan memberikan tingkat kepuasan terkait dengan konsumsi yang memuaskan. Dengan demikian, sangat berarti bagi perusahaan jasa untuk memahami lebih dalam terhadap tingkat persepsi pelanggan dalam layanan mereka. Giese dan Cote (2002), mendeskripsikan bahwa kepuasan pelanggan merupakan ringkasan tanggapan yang afektif dari berbagai intensitas, dengan penentuan waktu tertentu dan terbatas, dalam mengkonsumsi suatu produk. Chou dkk. (2014) menuliskan bahwa jika kualitas pelayanan bersifat positif, maka pelanggan cenderung mengunjungi kembali penyedia layanan tersebut. Maka dari itu, perusahaan cenderung meningkatkan kualitas pelayanan untuk memperoleh loyalitas pelanggan. Menurut Deng dkk. (2009), loyalitas pelanggan tidak hanya sebagai objek utama dalam pengukuran kepuasan pelanggan, tetapi juga merupakan penentu utama dari kelangsungan jangka panjang perusahaan tersebut. Apabila suatu perusahaan memperhatikan persepsi pelanggan terhadap kualitas pelayanan yang tinggi, maka pelanggan tersebut cenderung merasa puas dan loyalitas dalam dirinya pun meningkat (Minb \& Huu, 2016).

Berdasarkan uraian tersebut, penelitian ini dilakukan untuk mengetahui hubungan kualitas pelayanan dengan kepuasan pelanggan, kualitas pelayanan dengan loyalitas pelanggan, kepuasan pelanggan dengan loyalitas pelanggan, dan kepuasan pelanggan yang memediasi hubungan antara kualitas pelayanan dengan loyalitas pelanggan pada pelanggan transportasi daring di Jakarta.

\section{KAJIAN TEORI}

Menurut Kotler dan Keller (2016), consumer behaviour adalah studi tentang bagaimana individu, kelompok, dan organisasi memilih, membeli, menggunakan barang, layanan, ide, atau pengalaman untuk memenuhi kebutuhan dan keinginan mereka. Consumer behaviour dipengaruhi oleh tiga faktor, yaitu faktor kultural, sosial, dan personal. Faktor-faktor tersebut dapat menjadi petunjuk untuk meningkatkan dan melayani konsumen secara efisien (Kotler \& Keller, 2016).

Teori consumer behaviour berperan besar bagi suatu perusahaan. Dengan mengetahui consumer behaviour, maka manajer pemasaran dapat mengetahui serta mempelajari proses pengambilan keputusan pembelian konsumen serta faktor-faktor yang mempengaruhi konsumen. Consumer behaviour dapat disimpulkan sebagai tindakan konsumen dalam keputusan pembelian suatu produk atau jasa sesuai dengan keinginannya yang ingin dicapai.

\section{Hubungan antara Kualitas Pelayanan dan Kepuasan Pelanggan}

Pada penelitian Hapsari dkk. (2016), dijelaskan bahwa adanya hubungan yang signifikan antara kualitas pelayanan dan kepuasan pelanggan. Kepuasan pelanggan digambarkan sebagai suatu hasil perbandingan antara harapan pelanggan dan kinerja kualitas layanan yang dirasakan (Herrington \& Weaven, 2009). Salah satu elemen utama yang menentukan kepuasan pelanggan adalah persepsi pelanggan tentang kualitas pelayanan. 
Dengan demikian, berdasarkan uraian tersebut menjelaskan bahwa adanya hubungan positif antara kualitas pelayanan dan kepuasan pelanggan.

\section{Hubungan antara Kualitas Pelayanan dan Loyalitas Pelanggan}

Menurut Ismail dan Yunan (2016), kualitas layanan yang baik akan meyakinkan pelanggan untuk menggunakan kembali penyedia layanan tersebut. Ini menunjukkan perilaku pelanggan terhadap penyedia layanan. Kualitas layanan yang memenuhi harapan pelanggan akan memperoleh loyalitas pelanggan.

Kualitas pelayanan memiliki hubungan yang kuat dengan loyalitas pelanggan (Saura dkk., 2008). Kualitas dalam pelayanan dapat menimbulkan niat pelanggan untuk menggunakan pelayanan yang sama. Ini akan menimbulkan loyalitas pelanggan ke dalam bisnis (Ismail \& Yunan, 2016).

Dengan demikian, berdasarkan uraian tersebut menjelaskan bahwa adanya hubungan positif antara kualitas pelayanan dan loyalitas pelanggan.

\section{Hubungan antara Kepuasan Pelanggan dan Loyalitas Pelanggan}

Dalam penelitian Izogo dan Ogba (2015), memperlihatkan hubungan yang kuat antara kepuasan pelanggan dan loyalitas pelanggan. Kepuasan pelanggan dapat menimbulkan loyalitas pelanggan karena orang-orang cenderung lebih rasional dan mengurangi risiko pada penyedia layanan baru, sehingga mereka tetap pada penyedia layanan yang sudah memiliki pengalaman yang baik dengan mereka (Minb \& Huu, 2016).

Dengan demikian, berdasarkan uraian tersebut menjelaskan bahwa adanya hubungan positif antara kepuasan pelanggan dan loyalitas pelanggan.

\section{Kepuasan Pelanggan memediasi hubungan antara Kualitas Pelayanan dengan Loyalitas Pelanggan}

Dalam penelitian Akbar dan Parvez (2009), kepuasan pelanggan berperan sebagai mediator dan memediasi kualitas pelayanan dan loyalitas pelanggan. Menurut Lenka, Suar, dan Mohapatra (2009), mengungkapkan bahwa kualitas pelayanan melalui kepuasan pelanggan untuk menentukan loyalitas pelanggan, yaitu kepuasan pelanggan yang menimbulkan dorongan loyalitas mereka. Karena pelanggan yang puas akan bersikap loyal atau setia sehingga cenderung untuk memilih penyedia layanan yang sama.

Dengan demikian, berdasarkan uraian tersebut menjelaskan bahwa kepuasan pelanggan berperan positif sebagai mediator kualitas pelayanan dan loyalitas pelanggan.

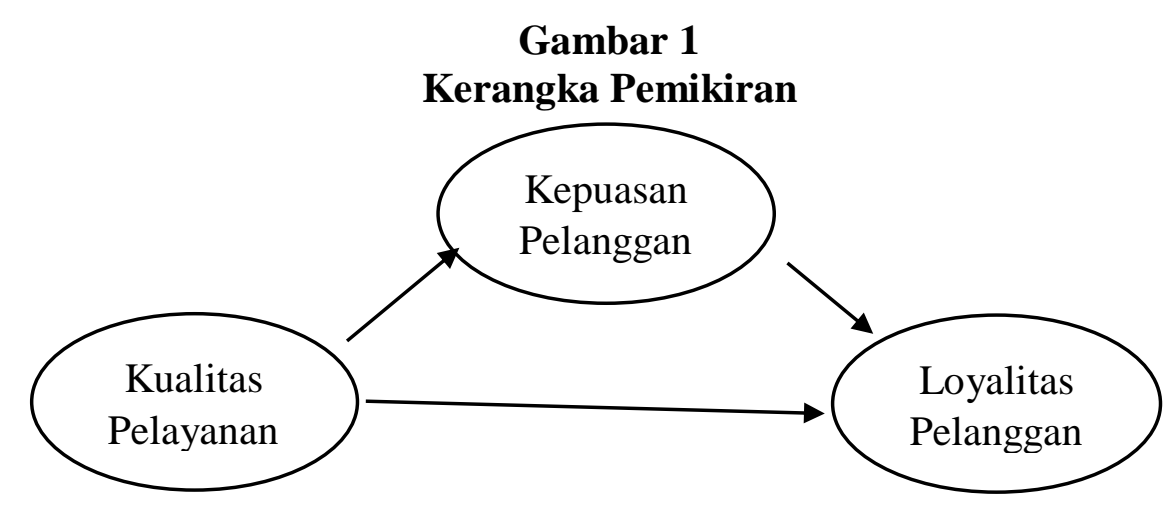




\section{METODOLOGI}

Desain penelitian yang digunakan dalam penelitian ini berupa penelitian deskriptif, yaitu untuk mendapatkan sebuah gambaran dan keterangan-keterangan respons dari pengguna jasa transportasi daring di Jakarta. Dalam penelitian ini menggunakan cross-sectional design dalam pengumpulan data sehingga tidak bersifat eksperimental. Populasi dalam penelitian ini adalah seluruh pelanggan jasa transportasi daring di Indonesia. Teknik dalam pengambilan sampel pada penelitian ini menggunakan metode non-probability sampling. Dalam penelitian ini, jenis metode yang diambil adalah purposive sampling. Dengan demikian, penelitian ini mengambil sampel hanya dari pelanggan yang menggunakan transportasi daring di Jakarta.

Pengumpulan data yang dilakukan dalam penelitian ini dengan pembagian kuesioner secara daring menggunakan google-form kepada pelanggan jasa transportasi daring di Jakarta. Tanggapan kuesioner yang digunakan adalah format skala Likert dengan skor indikator berkisar antara 1-5. Setiap indikator skala memiliki lima kategori respons, dimulai dari "sangat tidak setuju" hingga "sangat setuju" (Malhotra, 2010).

\section{HASIL ANALISIS DATA}

\section{Deskripsi Subjek Penelitian}

Dapat diperoleh data informasi berdasarkan domisili yang melibatkan sebanyak 100 responden dalam penelitian ini. Dari 100 orang responden dalam penelitian ini, responden terbanyak berdomisili di Jakarta Barat, yaitu sebanyak 55 responden (55\%) dan yang paling sedikit berdomisili di Jakarta Selatan dan Jakarta Utara, yaitu sebanyak 5 responden (5\%).

Dapat diperoleh data informasi berdasarkan jenis kelamin yang melibatkan sebanyak 100 responden dalam penelitian ini. Dari 100 orang responden dalam penelitian ini, dapat diketahui bahwa sebanyak 40 orang $(40 \%)$ adalah jenis kelamin laki-laki dan sebanyak 60 orang $(60 \%)$ adalah jenis kelamin perempuan.

Dapat diperoleh data informasi berdasarkan usia yang melibatkan sebanyak 100 responden dalam penelitian ini. Dari 100 orang responden dalam penelitian ini, responden terbanyak berusia 20-22 tahun, yaitu sebanyak 47 responden (47\%) dan yang paling sedikit berusia $>25$ tahun, yaitu sebanyak 12 responden (12\%).

Dapat diperoleh data informasi berdasarkan pendidikan terakhir yang melibatkan sebanyak 100 responden dalam penelitian ini. Dari 100 orang responden dalam penelitian ini, dapat diketahui bahwa responden terbanyak berpendidikan terakhir SMA/SLTA, yaitu sebanyak 62 responden $(62 \%)$ dan paling sedikit berpendidikan terakhir lainnya, yaitu sebanyak 6 responden $(6 \%)$.

Dapat diperoleh data informasi berdasarkan pekerjaan yang melibatkan sebanyak 100 responden dalam penelitian ini. Dari 100 orang responden dalam penelitian ini, dapat diketahui bahwa responden terbanyak adalah pelajar/mahasiswa, yaitu sebanyak 60 responden $(60 \%)$ dan yang paling sedikit adalah ibu rumah tangga, yaitu sebanyak 4 responden $(4 \%)$.

Dapat diperoleh data informasi berdasarkan pekerjaan yang melibatkan sebanyak 100 responden dalam penelitian ini. Dari 100 orang responden dalam penelitian ini, dapat diketahui bahwa responden terbanyak adalah pelajar/mahasiswa, yaitu sebanyak 60 responden $(60 \%)$ dan yang paling sedikit adalah ibu rumah tangga, yaitu sebanyak 4 responden $(4 \%)$. 


\section{Deskripsi Objek Penelitian}

\section{Kualitas Pelayanan}

Hasil dari tanggapan responden terhadap indikator variabel kualitas pelayanan yang terdiri dari 19 butir pernyataan. Data ini diperoleh dari 100 orang responden yang menunjukkan bahwa mayoritas responden menjawab setuju pada pernyataan-pernyataan yang tersedia pada tabel pernyataan variabel kualitas pelayanan. Pernyataan yang menghasilkan rata-rata tertinggi terdapat pada pernyataan pertama, ke-13, ke-18, dan ke-19 yaitu sebesar 4,170 pernyataan tersebut secara berurutan berisi "Jasa transportasi daring menyediakan sistem pelayanan yang menarik.", "Saya merasa aman dalam bertransaksi dengan transportasi daring.","Transportasi daring menyediakan jam operasional yang nyaman.", dan "Mudah menemukan dan mengakses transportasi daring." maka dari itu dapat disimpulkan bahwa responden menilai bahwa transportasi daring menyediakan sistem yang menarik, aman dalam bertransaksi langsung dengan transportasi daring, kenyamanan pada jam operasional, serta transportasi daring mudah ditemukan dan diakses. Kemudian, pernyataan yang menghasilkan rata-rata terendah terdapat pada pernyataan ke-15, yaitu sebesar 3,850 pernyataan tersebut berisi "Pekerja transportasi daring memiliki pengetahuan yang luas tentang pekerjaannya.", maka dari itu dapat disimpulkan bahwa responden menilai bahwa pekerja transportasi daring berpengetahuan luas akan pekerjaannya. Selanjutnya hasil pernyataan dengan standar deviasi terendah terdapat pada pernyataan kelima dengan skor 0,931 yang berisi "Transportasi daring selalu sampai tujuan dengan tepat waktu." Dapat dijelaskan bahwa pernyataan kelima memiliki skor yang tidak bervariasi. Pernyataan yang menghasilkan skor tertinggi adalah pernyataan pertama dan ketujuh dengan skor 1,123, yang berisi "Jasa transportasi daring menyediakan sistem pelayanan yang menarik." dan "Saya dapat melakukan pemesanan transportasi daring dengan mudah." Dapat dijelaskan bahwa pernyataan pertama dan ketujuh memiliki skor yang bervariasi.

\section{Kepuasan Pelanggan}

Hasil dari tanggapan responden terhadap indikator variabel kepuasan pelanggan yang terdiri dari 3 butir pernyataan. Data ini diperoleh dari 100 orang responden yang menunjukkan bahwa mayoritas responden menjawab sangat setuju pada pernyataanpernyataan yang tersedia pada tabel pernyataan variabel kepuasan pelanggan. Pernyataan yang menghasilkan rata-rata tertinggi terdapat pada pernyataan ketiga, yaitu sebesar 4,210 pernyataan tersebut berisi "Keputusan saya untuk bepergian menggunakan jasa transportasi daring adalah keputusan yang bijak.", maka dari itu dapat disimpulkan bahwa responden memiliki keputusan yang bijak dalam memilih bepergian dengan transportasi daring. Kemudian, pernyataan yang menghasilkan rata-rata terendah terdapat pada pernyataan kedua, yaitu sebesar 3,960 pernyataan tersebut berisi "Saya merasa memilih keputusan yang benar untuk bepergian menggunakan transportasi daring.", maka dari itu dapat disimpulkan bahwa responden merasa memiliki keputusan yang benar untuk menggunakan transportasi daring dalam bepergian. Selanjutnya hasil pernyataan dengan standar deviasi terendah terdapat pada pernyataan kedua dengan skor 1,048 yang berisi "Saya merasa memilih keputusan yang benar untuk bepergian menggunakan transportasi daring." Dapat dijelaskan bahwa pernyataan kedua memiliki skor yang tidak bervariasi. Pernyataan yang menghasilkan skor tertinggi adalah pernyataan pertama dengan skor 1,125, yang berisi "Secara keseluruhan, saya merasa puas dengan pelayanan transportasi daring." Dapat dijelaskan bahwa pernyataan pertama memiliki skor yang bervariasi. 


\section{Loyalitas Pelanggan}

Hasil dari tanggapan responden terhadap indikator variabel loyalitas pelanggan yang terdiri dari 5 butir pernyataan. Data ini diperoleh dari 100 orang responden yang menunjukkan bahwa mayoritas responden menjawab sangat setuju pada pernyataan-pernyataan yang tersedia pada tabel pernyataan variabel loyalitas pelanggan. Pernyataan yang menghasilkan rata-rata tertinggi terdapat pada pernyataan kelima, yaitu sebesar 4,180 pernyataan tersebut berisi "Saya akan merekomendasikan kepada orang-orang untuk bepergian menggunakan jasa transportasi daring.", maka dari itu dapat disimpulkan bahwa responden akan merekomendasikan transportasi daring kepada orang-orang. Kemudian, pernyataan yang menghasilkan rata-rata terendah terdapat pada pernyataan keempat, yaitu sebesar 3,930 pernyataan tersebut berisi "Saya akan berkata hal yang positif tentang jasa transportasi daring kepada orang-orang.", maka dari itu dapat disimpulkan bahwa responden akan berkata hal yang positif tentang transportasi daring. Selanjutnya hasil pernyataan dengan standar deviasi terendah terdapat pada pernyataan ketiga dengan skor 0,995 yang berisi "Saya akan mendorong orang-orang untuk menggunakan jasa transportasi daring." , dapat dijelaskan bahwa pernyataan ketiga memiliki skor yang tidak bervariasi. Pernyataan yang menghasilkan skor tertinggi adalah pernyataan kedua dengan skor 1,169 yang berisi "Saya akan bepergian menggunakan transportasi daring di masa depan." Dapat dijelaskan bahwa pernyataan kedua memiliki skor yang bervariasi.

\section{Uji Validitas (Convergent dan discriminant)}

Hasil analisis menunjukkan bahwa average variance extracted (AVE) dari setiap variabel pada penelitian ini memiliki koefisien yang lebih besar dari 0,5 yaitu kualitas pelayanan bernilai 0,672 , kepuasan pelanggan bernilai 0,847 , dan loyalitas pelanggan bernilai 0,762. Dalam penelitian ini, seluruh indikator dari setiap variabel memiliki nilai loading factor $>0,7$ sehingga dapat disimpulkan bahwa analisis ini memenuhi convergent validity yang diukur dari nilai loading factor. Berdasarkan analisis average variance extracted (AVE) dan loading factor dalam penelitian ini, menunjukkan bahwa setiap variabel-variabel yang diteliti memenuhi syarat yang ditentukan dalam convergent validity. Hasil pada penelitian ini dapat diketahui bahwa nilai akar kuadrat AVE setiap variabel lebih besar dari korelasi antar variabel sehingga memenuhi syarat Fornell Larcker criterion. Berdasarkan hasil pengujian cross-loading, menunjukkan bahwa nilai cross-loadings dari setiap indikator terhadap variabelnya sendiri memiliki nilai yang lebih besar apabila dibandingkan dengan variabel lainnya pada penelitian. Ini menyatakan bahwa nilai butir tersebut telah sesuai dan memenuhi kriteria cross-loadings.

\section{Uji Reliabilitas}

Berdasarkan hasil analisis reliabilitas dalam penelitian ini, maka dapat disimpulkan bahwa seluruh Cronbach's Alpha (Malhotra, 2010) dan composite reliability pada masing-masing variabel yang bernilai $\geq 0,6$ yaitu kualitas pelayanan menghasilkan cronbach's alpha sebesar 0,955 dan composite reliability 0,961, kepuasan pelanggan menghasulkan cronbach's alpha sebesar 0,908 dan composite reliability 0,943, dan loyalitas pelanggan menghasilkan cronbach's alpha 0,921 dan composite reliability 0,941. maka dapat disimpulkan bahwa variabel dalam penelitian ini merupakan variabel yang reliable. 


\section{Pengujian Inner Model}

\section{Koefisien Determinasi $\left(\mathbf{R}^{\mathbf{2}}\right)$}

Nilai R-square menunjukkan angka sebesar 0,914. Artinya sebesar 91,4\% dari variabel dependen yaitu loyalitas pelanggan dapat dijelaskan oleh variabel kualitas pelayanan dan kepuasan pelanggan dan sisanya yaitu sebesar 8,6\% (100\%-91,4\%) dijelaskan oleh variabelveriabel di luar dari penelitian ini. Koefisien determinasi atau R-square dalam penelitian ini tergolong subtansial (Hanseler, Ringle, \& Sinkovics 2009).

\section{Predictive Relevance $\left(\mathrm{Q}^{2}\right)$}

Berdasarkan hasil output yang diolah dengan software SmartPLS, nilai Q-square menunjukkan angka sebesar 0,644 $\left(\mathrm{Q}^{2}>0\right)$. Maka dapat disimpulkan bahwa variabel yang mempengaruhi loyalitas pelanggan yang berupa kualitas pelayanan dan kepuasan pelanggan dapat menunjukkan prediksi model yang baik dan memadai.

\section{Path Coefficient}

Berdasarkan pada hasil path coefficient dalam penelitian ini, dapat diperoleh persamaan dalam penelitian ini yaitu $\mathrm{LP}=0,733 \mathrm{KP}+0,241 \mathrm{KP}$. Hasil pengukuran path coefficient pada persamaan di atas menunjukkan bahwa hubungan antar variabel kualitas pelayanan, kepuasan pelanggan terhadap loyalitas pelanggan memiliki nilai path coefficient yang tergolong positif dengan nilai dari setiap model adalah 0,903, 0,733, dan 0,241.

\section{Goodness of Fit}

Berikut adalah rumus perhitungan manual goodness of fit:

$$
\begin{array}{r}
\overline{A V E}=0,760 \\
\overline{R^{2}}=0,863 \\
G o F=\sqrt{\overline{A V E} \times \overline{R^{2}}} \\
G o F=\sqrt{0,760 \times 0,863} \\
\text { GoF }=0,8098641861
\end{array}
$$

Maka dapat disimpulkan bahwa model yang digunakan dalam penelitian ini memiliki goodness of fit atau kecocokan model penelitian yang tergolong besar (Wetzels, Oderkerkenshroder dan Van Oppen, 2009).

\section{Hasil Analisis Mediasi}

Pengujian ini menghasilkan indirect effect yang menunjukkan nilai $t$-statistics sebesar 3,275 lebih besar dari nilai signifikansi minimum $(1,96)$ dan nilai $p$ values sebesar 0,001 lebih kecil dari nilai maksimum 0,05 dapat disimpulkan adanya signifikansi indirect effect dan hasil dari direct effect antara kualitas pelayanan dengan loyalitas pelanggan yang signifikan, yaitu $t$-statistics sebesar 10,899 dan nilai $p$ values sebesar 0,000 lebih kecil dari nilai maksimum 0,05. Dari hasil tersebut dapat disimpulkan bahwa pengaruh mediasi dari variabel kepuasan pelanggan adalah partial mediation. 


\section{PENUTUP}

Berdasarkan penelitian ini maka dapat disimpulkan bahwa kualitas pelayanan memiliki hubungan positif dengan kepuasan pelanggan pada pelanggan transportasi di Jakarta. Kualitas Pelayanan memiliki hubungan positif dengan loyalitas pelanggan pada pelanggan transportasi daring di Jakarta. Kepuasan pelanggan memiliki hubungan positif dengan loyalitas pelanggan pada pelanggan transportasi daring di Jakarta. Kepuasan pelanggan dapat memediasi secara positif hubungan antara kualitas pelayanan dengan loyalitas pelanggan pada pelanggan transportasi daring di Jakarta.

Bagi perusahaan transportasi daring, disarankan agar perusahaan transportasi daring memaksimalkan kualitas pelayanan, sehingga meningkatkan kepuasan pelanggan serta memperoleh loyalitas dan membuat pelanggan merekomendasikan jasa transportasi daring kepada yang lainnya. Bagi peneliti selanjutnya, disarankan untuk menambahkan variabelvariabel lain di luar variabel yang telah dibahas dalam penelitian ini dan variabel lain yang memiliki hubungan dengan loyalitas pelanggan seperti product quality, brand image, trust, dan lain-lain. Bagi peneliti selanjutnya, disarankan untuk pengambilan sampel yang dapat mewakili setiap wilayah yang telah ditentukan dalam penelitian agar setiap responden dapat mewakili subjek penelitian yang sesuai.

\section{DAFTAR PUSTAKA}

Akbar, M. M., \& Parvez, N. (2009). Impact of service quality, trust, and customer satisfaction on customer loyalty. ABAC Journal, 29(1), 24-38

Aydin, S., Özer, G. \& Arasil, O. (2005) Customer loyalty and the effect of switching costs as a moderator variable: a case in the Turkish mobile phone market, Marketing Intelligence \& Planning, 23(1), 89-103.

Bitner, M. J. \& Zeithaml, V. A., 2003, Service Marketing Third Edition. Tata McGraw Hill: New Delhi.

Bowen, J. T., \& Chen, S. (2001). The relationship between customer loyalty and customer satisfaction. International Journal of Contemporary Hospitality Management, 13(5), 213-217.

Chang, N. J. \& Fong, C. M. (2010). Green product quality, green corporate image, green customer satisfaction, and green customer loyalty. African Journal of Business Management, 4(13), 2836-2844.

Chen, P. H. (2008). The relationship among experiential marketing, brand image, and customer loyalty: an empirical study of Lavender Cottage in Hsinchu. Department of Business Administration, Yu Da University of Science and Technology, Taiwan.

Chou, J. S., Kim, C., Kuo, Y. C., \& Ou, N. C. (2011). Deploying effective service strategy in the operation stage of high-speed rail. Transportation Research Part E: Logistics and Transportation Review, 47(4), 507-519.

Chou, P. F. (2014). An evaluation of service quality, trust, and customer loyalty in homedelivery services. International Journal of Research in Social Sciences, 3(8). 99-108.

\& Lu, C. S. (2009). Assessing service quality, switching costs and customer loyalty in home-delivery services in Taiwan. Journal Transport Reviews, 29(6), 741758 
., Lu, C. S., \& Chang, Y. H. (2014). Effects of service quality and customer satisfaction on customer loyalty in high-speed rail services in Taiwan. Transportmetrica A: Transport Science, 10(10), 917-945.

Chou, P., \& Lu, C. (2009). Assessing service quality, switching costs and customer loyalty in home-delivery services in Taiwan. Journal Transport Reviews, 29(6), 741-758

Clarke III, I. (2001). Emerging value propositions for m-commerce. Journal of Business Strategies, 18(2), 133-148

Deng, Z., Lu, Y., Wei, K. K., \& Zhang, J. (2010). Understanding customer satisfaction and loyalty: an empirical study of mobile instant messages in China. International Journal of Information Management, 30(4), 289-300.

Farin, N. J., Rimon, M. N. A. A., Momen, S., Uddin, M. S., \& Mansoor, N. (2016). A framework for dynamic vehicle pooling and ride-sharing system. In Computational Intelligence (IWCI).

Farris, P. W., Bendle N. T., Pfeifer P.E., \& Reibstein, D. J. (2010). Marketing Metrics: The Definitive Guide to Measuring Marketing Performance. Pearson Education.

Giese, J. L., Cote, J. A. (2002). Defining consumer satisfaction. Academy of Marketing Science Review, 2000(1).

Hair, J., Ringle, C., \& Sarstedt, M. (2011). PLS-SEM: Indeed A Silver Bullet. The Journal of Marketing Theory and Practice, 19(2), 139-151.

, Sarstedt, M., Hopkins, L., \& G. Kuppelwieser, V. (2014). Partial least squares structural equation modeling (PLS-SEM). European Business Review, 26(2), 106121. doi:10.1108/ebr-10-2013-0128

Hanseler, J., Ringle, C., \& Sinkovics, R. (2009). The use of partial least square path modeling in international marketing. Advances in International Marketing, 20, 277-319.

Hansemark, O. C., \& Albinsson, M. (2004). Customer satisfaction and retention: the experience of individual employees. Managing Service Quality, 14(1), 40-57.

Hapsari, R., Clemes, M. and Dean, D. (2016). The mediating role of perceived value on the relationship between service quality and customer satisfaction: Evidence from Indonesian Airlines Passengers. Procedia Economics and Finance, 388-395.

Herrington, C., \& Weaven, S. (2009) E-retailing by banks: e-Service quality and its importance to customer satisfaction. European Journal of Marketing, 43(9), 12201231.

Huang, E. Y., Lin, S. W., \& Fan, Y. C. (2015). MS-QUAL: Mobile Service Quality Measurement. Electronic Commerce Research and Applications.

Ismail, A., \& Yunan, Y. S. M. (2016). Service quality as a predictor of customer satisfaction and customer loyalty. Scientific Journal of Logistics, 12(4), 269-283.

Izogo, E. E., \& Ogba, I. E. (2015). Service quality, customer satisfaction and loyalty in automobile repair services sector. International Journal of Quality \& Reliability Management, 32(3), 250 - 269.

Kim, H. J. (2011). Service orientation, service quality, customer ssatisfaction, and customer loyalty: testing a structural model. Journal of Hospitality Marketing \& Management, 20(6), 619-637.

Kim, H. S., \& Yoon, C. H. (2004). Determinants of subscriber churn and customer loyalty in the Korean mobile Telephony Market. Telecommunications Policy, 28(9-10), 751765.

Kotler P. \& Armstrong G. (2006). Principles of marketing 11th Edition. Upper Saddle River: New Jersey: Prentice-Hall. 

Inc.

\& Keller, K. L. (2016). Marketing Management 15th Edition. Pearson Education,

Lee, G. G., \& Lin, H. F. (2005). Customer perceptions of e-service quality in online shopping. International Journal of Retail \& Distributions Management, 33(2), 161176.

Lee, H. S. (2013). Major moderators influencing the relationships of service quality, customer satisfaction and customer loyalty. Asian Social Science, 9(2).

Lenka, U., Suar, D., \& Mohapatra, P. K. J. (2009). Service quality, customer satisfaction, and customer loyalty in Indian commercial banks. The Journal of Entrepreneurship, 18(1), 47-64.

Liu, W. K., Lee, Y. S., \& Hung, L. M. (2016). The interrelationship among service quality, customer satisfaction, and customer loyalty: examination of the fast-food industry. Journal of Foodservice Business Research, 20(2), 146-162.

Maholtra, N. K. (2010). Essentials of Marketing Research. England: Pearson Educated Limited.

Millia, J. I. (2017). Impact of internet banking service quality on customer satisfaction. Journal of Internet Banking and Commerce, 22(1).

Minb, N. V., \& Huu N. H. (2016). The relationship between service quality, customer satisfaction and customer loyalty: an investigation in Vietnamese retail banking sector. Journal of Competitiveness, 8(2), 103-116

Motala, M. (2016) "The 'Taxi Cab Problem' revisited: law and ubernomics in the sharing economy," Banking and Finance Law Review, 468-511.

Salameh, A. A., \& Hassan, S. B. (2015). Measuring service quality in m-commerce context: a conceptual model. International Journal of Scientific and Research Publications, 5(3), 2250-3153.

Santouridis, I., \& Trivellas, P. (2010). Investigating the impact of service quality and customer satisfaction on customer loyalty in mobile telephony in Greece. The TQM Journal, 22(3), 330-343.

Saura, G. I., Francés, S. D., Contrí, B. G., \& Blasco, F. M. (2008). Logistics service quality: a new way to loyalty. Industrial Management \& Data Systems, 108(5), 650-668.

Sekaran, U., \& Bougie, R. (2013). Research Methods for Business $6^{\text {th }}$ ed. Italy: Printer Trento Srl.

Shin, D.-H., \& Kim, W. Y. (2008). Forecasting customer switching intention in mobile service: an exploratory study of predictive factors in mobile number portability. Technological Forecasting and Social Change, 75(6), 854-874.

Silalahi, S. L. B., Handayani, P. W., \& Munajat, Q. (2017). Service quality analysis for online transportation services: case study of GO-JEK. Procedia Computer Science, $124,487-495$.

Tenenhaus, M., Vinzi V. E., Chatelin, Y. M., \& Lauro, C. (2005). PLS Path Modeling. Computational Statistics \& Data Analysis, 48(1), 159-205.

Tuu, H. H., Olsen, S. O., \& Linh, P. T. T. (2011). The moderator effects of perceived Risk, objective knowledge and certainty in the satisfaction-loyalty relationship. Journal of Consumer Marketing, 28(5), 363-375

Uncles, M. D., Dowling, G. R., \& Hammond, K. (2003). Customer loyalty and customer loyalty programs. Journal of Consumer Marketing, 20(4), 294-316.

Wallsten, S. (2015). The competitive effects of the sharing economy: how is uber changing taxis. Technology Policy Institute. 
Wetzels, M., Odekerken-Schroder, G., \& Oppen, C. (2009). Using PLS Path modelling for assessing hierarchical construct models: guidelines and empirical illustration. Assessing Hierarchical Construct Models, 33(1), 177-195.

Wong, A., \& Sohal, A. (2003). Service quality and customer loyalty perspectives on two levels of retail relationships. Journal of Services Marketing, 17(5), 495-513.

Wu, M. Y., \& Tseng, L. H. (2014). Customer satisfaction and loyalty in an online shop: an experiential marketing perspective. International Journal of Business and Management, 10(1).

https://www.cnbcindonesia.com/news/20180217144830-4-4629/mengenal-penguasatransportasi-online-di-berbagai-negara

https://www.idntimes.com/business/economy/putriana-cahya/persaingan-tiga-transportasionline-terbesar 